\title{
Immense Potential of the Fisheries Industry as a Contributor to Oman's Exports and Economic Development
}

\author{
Adela P. Balasa Noorul Shaiful Fitri Abdul Rahman* \\ Department of Logistics Management, International Maritime College Oman, PO Box 1532 Sohar, Sultanate of \\ Oman
}

\begin{abstract}
Over the past 40 years, Oman has exhibited remarkable growth in various sectors such as infrastructure, retailing, manufacturing services and heavy industry. However, fisheries and related industries did not see much growth in the real sense. Previously, fish production in 2012 grew by $21 \%$ compared to 2011 and reached 191,000 tons in volume (or OMR142 million in value), striking an average growth rate of $6 \%$ between 2009 and 2012. Thus, the aim of this study is to explore the fisheries industry in Sultanate of Oman that could eventually help in Oman's exports and economic development. The exploratory research and descriptive method that involving surveys and interview have been used in this study. As evident, three states of Oman being studied in this research: Sohar, Muscat and Salalah. Finally, the study found that the type of transportation used by the fishermen be traditional and modern boat because it has a significant relationship to the immense presence of fishes in the Arab waters. Traditional type of fishing boat can catch as many as $0-300$ tons, while modern type boat can catch $0-500$ tons of fish whenever they go fishing. This scenario can bring forth a better view on how Omani people can prosper vis-a-vis with Oman's economic diversification where the government and the Omani people will unite with one purpose.
\end{abstract}

Keywords: Fisheries Industry, Oman; Exploratory, Commercial Fisherman, Artisanal Fisherman

DOI: $10.7176 / \mathrm{EJBM} / 12-12-06$

Publication date: April $30^{\text {th }} 2020$

\section{Introduction}

Marine water borders around the Middle East countries is surrounded by the Mediterranean Sea on the north, the Atlantic Ocean on the west, the Arabian Gulf on the east, and the Indian Ocean on the south. Furthermore, there are also various gulfs and rivers like Nile, Euphrates and the Tigris along with the presence of the Red Sea and the natural and man-made lakes that consist of inland water resources that the Arab countries deem to provide a very high potential for fisheries.

Before oil was discovered in some Arab states, fish has been an important source of revenue that comes particularly at the coastal areas too. Due to various economic and social reasons, demand for fish and its consumption in fresh or processed form have risen to some degree. Fish marketing opportunities are increasingly being modernized in the Arab states like in Oman.

Oman, with its long coastal line of 3,262 kilometres, has great potential to develop the fisheries sector to serve global markets. The fisheries industry is one of the promising sectors in diversifying sources of national income, creating job opportunities and ensuring high value-added products according to the Times of Oman on July 11 (2017).

There are two types of fishery in Oman and they are coastal and artisanal fishery and commercial fishery. The coastal and artisanal fishermen are the licensed, full- and part-time fishermen using limited gears and vessels that represent $96 \%$ (18,031 boats) with total overall length between 5 and 9 meters (Al-Habsi (2012). They also use coastal fishing ships which are mainly used in the east of Oman with the length of between 12- 32 meters according to Al-Habsi (2012). Commercial fishery on the other hand, is represented by modern fishing ships, using developed techniques and gears for fishing. These ships are hired by Omani fishing companies to fish in predetermined areas and specific quota set by the Ministry of Agriculture and Fisheries (MoAF) where each ship has a government watcher or MoAF representative to ensure that the ship is fishing according to fishing regulations of Oman and in the areas that are authorized fish. There is also a satellite surveillance in addition to the watcher to double check if rules set are followed to avoid conflicts or further conflicts among fishermen and fishing companies.

Oman's fisheries sector alone has plenty of potential to boost the contribution it makes to the country's economy and become a world-class competitive industry. According to Khan (2017), the World Bank group has supported the fisheries sector in the sultanate with wide-ranging policy and technical advice through a reimbursable advisory service (2014-2016). Although, 99 percent of Oman's fisheries sector is still considered artisanal, its fisheries are just a few steps away from becoming a world-class competitive industry. Currently, Oman's fisheries industry only looks at the harvesting sector or the fishing itself that contributes just 0.7 percent to its Gross Domestic Products (GDP) in 2015. With its immense potential in fishing given the fact that its location is surrounded by waters, an entire value chain should be included from harvesting to processing to logistics, to wholesale, marketing, retail and export. If this chain will be done, the current contribution of the fisheries industry 
would be doubled, and Oman's economy be doubled as well. In this scenario, Oman's development would also benefit from greater attention to markets, domestic and international, from high value fisheries, instead of just the volume of fish landed which would also help create new and more jobs in the country.

According to Muscat Daily news article dated September 19, 2018 the Ministry of Agriculture and Fisheries (MoAF) aims to increase the fisheries sector's contribution to the GDP taking it to RO1.3 billion in 2023 from RO225 million in 2016. In order to achieve this target, the MoAF is expecting to raise fish production to $1.4 \mathrm{mn}$ tons in 2023 from 280,000 tons in 2016. This is projected by the undersecretary in MoAF, H E Dr. Hamad bin Said al Oufi at a fisheries and aquaculture workshop held in Oman Chamber of Commerce and Industry (OCCI). He further said that according to the World Bank (WB), Oman's fishing industry is only a few steps away from reaching a competitive industry status of global scale and that the ministry is also working to streamline processes involved in setting up fisheries-related businesses in Oman. Thus, this will eventually make way for Oman's economy to be boosted even more through the immense potential of its fisheries industry. This workshop has challenged the MoAF and the fisheries sectors of Oman to do some fast tracking and simplifying business procedures in fishing. Creating more bilateral investment opportunities in fisheries industry, the French Ambassador, H E Renaud Salins mentioned that fisheries sector in Oman is one of the top priorities of the economic diversification strategy of the sultanate and is ready to share the French experience in using latest technology in fisheries. This will eventually create a bilateral investment opportunity in fisheries between Omani and French companies.

Looking at the immense potential of fisheries industry in Oman on the possible growth and business opportunities, private sectors are encouraged to partner with the MoAF and are expected to contribute to the GDP by RO556mn, increasing the contribution of the fisheries sector by more than three times the contribution in 2016 , to reach RO781 mn by 2023 according to Muscat Daily staff writer on November 1, 2017. This endeavour has led dignitaries to the workshop on fisheries and aquaculture where it encouraged bilateral investment with other nations particularly France. These initiatives and projects envisaged by the MoAF in partnership with the private sectors of Oman are expected to increase the economy of Oman through the fisheries industry.

This study highlights the immense potential of fisheries industry as a contributory factor to Oman's exports and its economic development. Moreover, it will also determine how local fishermen, fishing companies and Omanis will benefit with this economic growth and development.

\section{Literature Review}

Mubeen, et.al (2017), emphasized on giving more importance to entrepreneurship development to bring out the talents and provide better opportunities to the Omanis instead of depending upon employment. He further mentioned in his study that diversification is needed to stabilize earnings and increase the revenue of the whole economy. Diversification can be done by promoting industrial sector to increase their output by satisfying the demand in the local market as well as making large export which in turn increase the economy as a whole. Government can also help in promoting and attracting foreign direct investments. Infrastructure need to be upgraded and Financial restructuring i.e. interest rates need to be moderate so that it helps the private entrepreneurs to take loan and the market for non-oil products can be encouraged. Marketing of tourism can also be one of the alternatives to develop economy.

Belwal, et.al. (2015), in their study, The Fisheries of Oman: A situation Analysis, presents the artisanal fishermen on the Al-Batinah coast of Oman and found that the majority of the fishermen on the Batinah coast were not appropriately educated and trained. Most of them followed irregular routines, earned a little money from fishing, have low savings, faced financial constraints, and lack knowhow of modern dishing techniques and postharvest dealings. The fishermen's performance over several variables revealed a need for a consolidated marine policy that takes a consideration a host of issues related to the governance of artisanal fisheries and its sustainability and contribution to the economic activities of Oman.

Bose,et.al. (2017), studied Traditional Fisheries enforcement program: a case of three coastal villages in the eastern part of Oman revealed the efficacy of the existing enforcement programs of the artisanal fisheries sector of Oman. Al-Oufi, et.al. (2000), discussed on observations upon the Al-Batinah artisanal fishery, the Sultanate of Oman with a consequence of socio-economic information upon the region and examine the industry's structure and co-management strategies. It also includes the sizes of the fishing vessels used. Average income per person, and the education of the fishermen.

Setlur and Arbuckle (2015) in their journal review on Sustainable Management of the Fisheries sector of Oman: A vision for shared prosperity said it is expected that future employment opportunities in the sector will focus on building technical management business expertise in the fisheries sector. They further mentioned that the World Bank supports stakeholders and government in reviewing four high-value fisheries and creating the new management structure to guide, regulate and enforce fishery management.

Moustafa, et. al., (1998) in their study on the status of fish biodiversity in the Sultanate of Oman, they discovered that the major problems of the artisanal fishery in Oman are the overfishing of some commercial species 
and the degradation of coastal habitats. Although several measures already exist, they said, there is no specific policy or management plan for any commercially exploited species so there is an urgent need for plans containing directives and specific actions to meet the goal of maximizing the social and economic benefits resulting from harvesting fish while conserving stocks to ensure sustainable levels. It was further suggested that plans should also be developed to establish protected areas for nursery and spawning of fishes.

Al-Habsi (2012), in his study entitled: Fisheries sustainability in Oman reiterated that future works needs to address possible alternatives of fisheries management, e.g. involve the fishermen in the management of the sector through well-organized institutions. Overcoming this vicious cycle requires major policy initiatives which help organize a process that balances interests of individual fishermen and supports negotiation of quotas within sustainability limits. Involvement of stakeholders is as important as incorporating the best available scientific information about the complex interactions and the data that feed into models. Further, he said that developing adaptive co-management frameworks that allow for social learning is essential to overcome the tragedy of the commons in fishery.

Al-Belushi, et. al., (2015) on the development of marine biotechnology in Oman: potential for capacity building through open innovation, examined the current state of the art in the emerging and strategically important marine biotechnology sector in Oman, which has a long coastline, rich marine heritage and strong fishing industry. It was further stated in this study that in a knowledge-based economy, the ability to innovate is a key factor increasing organizational competitiveness and this may be achieved using open innovation. In addition, they said, that the use of open innovation to increase collaboration between companies, universities and government research institutes needs to be significantly strengthened.

Al-Abri, (2019) in his article entitled: Omani fish exports soar to record 245,000 tonnes: according to AlAbri's statistical report information, Al Wusta Governorate was ranked first in artisanal fishery with 37 per cent of the total catch in 2018, followed by South al Sharqiya (28 per cent), Al Batinah North and South (12 per cent) and Dhofar (12 per cent), Musandam (6 per cent) and Muscat (5 per cent). He added that, small pelagic fish made up 62 per cent of the total output of the artisanal fisheries sector. The author further reported that large pelagic fish production accounting for 18 per cent of the share, Demersal fish species contributing 14 per cent and crustaceans 3 per cent. He concluded that the decrease of Omani fish exports is attributed to two main reasons: suspension of small fishing vessels since 2011 and the decrease in the number of long-line fishing vessels that are operating over the past four years (2015-2018). Finally, he mentioned that the contribution from industrial fisheries came from a solitary operating ship in 2018.

Al-Habsi and Nik Mustapha (2011), on their reviewed journal of fisheries sector in the Sultanate of Oman entitled: Fisheries Sustainability in Oman: fisheries and agriculture sectors have always been important to Oman, providing a valuable source of employment and food security. They added on their review that before the detection, and subsequent exploitation of oil in the late 1960s, the two sectors dominated the Omani economy and supported around $80 \%$ of the population. They emphasized that even today, approximately $50 \%$ of the populations rely upon fisheries and agriculture as a source of income and together, the two sectors retain major prominence in terms of the renewable resource economy. Further on their review, a 200-mile exclusive economic zone extends to seaward from the shores of Oman and has a huge variety of fish, some of which are not yet exploited and based on their study currently the fisheries sector represents close to $1 \%$ of the total GDP.

These related studies support the immense potential of the fisheries industry become a contributor to Oman's exports and economic development given the fact that Oman is surrounded with bodies of water that are rich in different kinds of fishes whether these fishes be caught by artisanal or commercial fishermen, when these Omanis collaborate with each other, then the economy of Oman will be strengthened and fully developed.

\section{Methodology}

Descriptive research design was used, and the data were collected through secondary sources from internet, respondents and journal research articles. Effective approaches such as participatory and conventional survey on gathering data were used by the researcher.

This study aimed to determine the immense potential of the fisheries industry as a contributor to Oman's exports and economic development. It highlights the importance of Omani fishermen as main players in this sector and the types of fishing transportation these Omani fishermen are using whenever they go for fishing. It specifically seeks to answer the following questions:

a) What are the fish species that are abundant in the Arab waters?

b) What type of fishing transportation is used in fishing in terms of:

i. Traditional boats; and

ii. Modern boats/vessel?

c) What implications can traditional boats and modern boats/vessels contribute to Oman's exports and economic development knowing the immense potential of the fisheries industry?

d) Is there a significant relationship between the type of fishing transportation the respondents use in 
fishing and the implications it contributes to Oman's exports and economic development knowing the immense potential of the fisheries industry?

While the study also adopted the IPO model approach as an overall conceptual framework (Figure 1), the researcher focused on the kind of fish species that are abundant in the Arab waters in the Arabian sea and the type of fishing transportation used by the Omani fishermen whenever they go fishing. Analysis points out the details gathered from the survey questionnaire from the 300 respondents from Sohar Albatinah, Salalah Al Dofar and Muscat Governorate, Sultanate of Oman respectively. Frequency Count was also used to determine the significant relationship between the variable presented in this study. Data gathered in this study to obtain the necessary information in order to reject the null hypothesis presented in this research.

INPUT

List of the fish species and fish
products that are abundant in
the Arab waters; and
The type of fishing
transportation used in
catching fish.

PROCESS

Implications that the type of
transportation used in catching
fish contribute to exports and
economic development of
Oman as perceived from the
survey questionnaire.

\section{OUTPUT}

Significance of having good type of transportation to be used in catching fish and the list of productivity and contribution of the fisheries industry in exports and economic development of Oman

Figure 1. Conceptual Framework

\section{Findings}

This section determines the immense potential of the fisheries industry as a contributor to Oman's exports and economic development. It also points out the details gathered from the survey questionnaire from the 300 respondents from Sohar Albatinah, Salalah Al Dofar and Muscat Governorate, Sultanate of Oman respectively.

Table 1. Fish Species abundant in Arab waters - Sohar Al Batinah Region

\begin{tabular}{|l|c|c|c|}
\hline \multirow{2}{*}{\multicolumn{1}{c}{ Fish species }} & Most abundant & Abundant & Somewhat Abundant \\
\cline { 2 - 4 } & (Percentage - \%) & (Percentage - \%) & (Percentage - \%) \\
\hline Sultan Ibrahim Fish & 64 & 18 & 46 \\
\hline Norwegian Salmon fish & 34 & 20 & 14 \\
\hline Seema fish & 48 & 38 & 21 \\
\hline King fish & 45 & 34 & 58 \\
\hline Tilapia or Cichlid fish & 28 & 14 & 26 \\
\hline Crabs Oman & 26 & 48 & 32 \\
\hline Tuna Fish & 20 & 48 & 20 \\
\hline Sherry fish & 40 & 40 & 41 \\
\hline Mackerel & 14 & 45 & 45 \\
\hline Unknown fish & 15 & 40 & \\
\hline
\end{tabular}

Table 1 shows the different fish species that are abundant in the Arab waters particularly in Sohar, Al-Batinah region. It denotes that in Sohar, the most abundant fish species is the Sultan Ibrahim fish among the ten species listed above where a total of 64 or $64 \%$ of the respondents agreed on. Seema fish ranks second with a total of $48 \%$ followed by the King fish 45\%, Sherry fish 40\%, Norwegian Salmon fish 34\%, Tilapia or Cichlid fish 28\%, Crabs Oman 26\%, Tuna fish 20\%, Unknown fish 15\% and Mackerel 14\% respectively. On the other hand, Tilapia or Cichlid fish is somewhat abundant in Sohar with 58\%, as this kind of fish thrives better in fresh water or in ponds. It is rare to find Tilapia in sea water not unless the fingerlings are highly cultured and are susceptible to living in sea water. Tilapia is followed by Norwegian Salmon fish 46\%, Unknown fish 45\%, Mackerel 41\%, Tuna 32\%, Crabs Oman 26\%, King fish 21\%, Sherry fish 20\%, Sultan Ibrahim fish $18 \%$ and Seema fish 24\% respectively under Somewhat abundant. This data implies that even if these list of fish are somewhat abundant; it still contributes to the Omani economy. As per the law of supply and demand, when demand is high and the goods/products are rare, the more the price of the commodity grows higher. Thus, the more the fishermen catch these rare fish species to sell, the more income they will have, the more the exports and the more economy of Oman rises. 
Table 2. Fish Species abundant in Arab waters - Muscat Governorate

\begin{tabular}{|l|c|c|c|}
\hline \multirow{2}{*}{\multicolumn{1}{c}{ Fish Species }} & Most abundant & Abundant & Somewhat Abundant \\
\cline { 2 - 4 } & (Percentage - \%) & (Percentage - \%) & (Percentage - \%) \\
\hline Sultan Ibrahim fish & 68 & 22 & 10 \\
\hline Norwegian fish & 33 & 14 & 53 \\
\hline Seema fish & 38 & 57 & 4 \\
\hline King fish & 33 & 63 & 4 \\
\hline Tilapia or Cichlid fish & 31 & 65 & 56 \\
\hline Crabs Oman & 30 & 14 & 60 \\
\hline Tuna fish & 25 & 15 & 52 \\
\hline Sherry fish & 29 & 19 & 58 \\
\hline Unknown fish & 23 & 19 & 42 \\
\hline Mackerel & 16 & 42 & \\
\hline
\end{tabular}

Table 2 displays the fish species abundant in the state of Muscat. It shows that Sultan Ibrahim fish got the highest percentage under the "Most abundant" column with a percentage of 68 leaving half a percent of its score compared to the other fish species shown above. However, in this state, Tuna fish got $60 \%$ on "Somewhat abundant" followed by the unknown fish (58\%), Crabs Oman (56\%), Norwegian Salmon fish (53\%), Sherry fish (52\%), Mackerel (42\%), Sultan Ibrahim fish (10\%), Seema fish (5\%) and King Fish and Tilapia both got 4\% respectively. As observed from the table above, six out of ten fish species are under the "Somewhat abundant" column. Since the state of Muscat is the City proper of Oman, this implies that most people make use of tuna, salmon, sherry fish and the three other fish species that got a high percentage in "Somewhat abundant" column, more so to attract foreign visitors in the area as observed also by one of the fishermen respondents. Hence, the fish species that are "Most abundant" and "Abundant" in the area show high potential in the economic development of Oman. Thus, residents and even the Omani government will pave way for this development. Working hand in hand will not make all these fishes go to waste but will help uplift the standard of living of the fishermen and all Omanis and the government as well.

Table 3 displays the fish species abundant in Salalah state. It is observed that Sultan Ibrahim Fish is the "Most abundant" fish with 68\% which is true in the two aforementioned states being studied upon. However, same observation is also seen on Sherry fish $68 \%$, Norwegain salmon fish $66 \%$, Tuna fish $66 \%$ and the unknown fish $66 \%$ that are under "Somewhat abundant". These type of fish species may be more in demand in the area. Same is true in the state of Muscat where these types of fishes attract people more. This implies further that Arab waters have immense potential in the fishery industry. Thus, it can contribute much on the economic development of Oman and its constituents. Proper care, good governance/management of these potentials will contribute even more to Oman's economic diversification.

Table 3. Fish Species abundant in Arab waters - Salalah Al Dhofar Region

\begin{tabular}{|l|c|c|c|}
\hline \multirow{2}{*}{\multicolumn{1}{c}{ Fish species }} & Most abundant & Abundant & Somewhat Abundant \\
\cline { 2 - 4 } & (Percentage - \%) & (Percentage - \%) & (Percentage - \%) \\
\hline Sultan Ibrahim fish & 68 & 22 & 10 \\
\hline Norwegian fish & 24 & 10 & 66 \\
\hline Seema fish & 44 & 44 & 12 \\
\hline King fish & 42 & 48 & 13 \\
\hline Tilapia or Cichlid fish & 31 & 56 & 16 \\
\hline Crabs Oman & 24 & 60 & 66 \\
\hline Tuna fish & 22 & 12 & 68 \\
\hline Sherry fish & 18 & 14 & 14 \\
\hline Mackerel & 24 & 62 & 66 \\
\hline Unknown fish & 18 & 16 & \\
\hline
\end{tabular}

Table 4 shows that out of 100 fishermen in Sohar, 93 fishermen use traditional fishing transportation like small to big boats and even coastal fishing ships. On the other hand, out of 100 respondents only 7 fishermen use modern fishing ships. In Salalah, 93 fishermen use traditional fishing transportation and 5 fishermen use modern transportation. Both Sohar and Salalah are still not much equipped when it comes to modern transportation in catching fish as compared to that of Muscat where 15 respondents said that they use modern transportation like big ships/vessels while 85 of the respondents in Muscat still use traditional transportation. The retrieved data implies further that as the area obtains more modern in their way of living, better and greater technologies surface just like in Muscat. This observation does not deter any fishermen from fishing because, Arab waters have immense potential when it comes to different kinds of fishes. According to all respondents from three states of Oman, type of fishing transportation used in fishing is described in Table 4. 
Table 4. Type of Fishing Transportation

\begin{tabular}{|l|c|c|c|}
\hline Type of Transportation & Sohar & Muscat & Salalah \\
\hline Traditional & 93 & 85 & 95 \\
\hline Modern & 7 & 15 & 5 \\
\hline Total & $\mathbf{1 0 0}$ & $\mathbf{1 0 0}$ & $\mathbf{1 0 0}$ \\
\hline
\end{tabular}

Table 5 denotes the number of fishes caught by the Omani fishermen using either traditional or modern transportation. In Sohar, 45 fishermen used traditional transportation in fishing and are able to catch 0-100 tons of fish; 38 fishermen who also make use of traditional fishing said that they catch $101-200$ tons of fish while 10 of them who also make use of traditional transportation catches $201-300$ tons of fishes. On the other hand, 7 fishermen said that they make use of modern transportation in fishing and can catch $201-300$ tons of fish. In Muscat, 22 fishermen make use of traditional transportation and catch 0 -100 tons of fish; 15 fishermen catch 101 - 200 tons while 48 fishermen catch $201-300$ tons whenever they go out fishing. Some fishermen in Muscat make use of modern type of transportation where 3 of them catch $201-300$ tons of fishes; 2 of them catch 2301 -400 tons and 10 of them catch $401-500$ tons of fishes whenever they go fishing. The data indicates that using modern method in fishing means higher volume in their catch unlike using traditional type of transportation in fishing. In Salalah, 15 fishermen catch $0-100$ tons of fish; 25 fishermen catch $101-200$ tons of fish while 55 of them catch $201-300$ tons of fish whenever they go on fishing using traditional type of transportation. There are 3 fishermen who catch $101-200$ tons of fish and 2 others catch $201-300$ tons of fish using modern type of transportation whenever they go out fishing. These implies that fishermen in Salalah still make use more of traditional type of transportation in fishing than the modern transportation because 95 out of 100 respondents made this evident while only 5 respondents made use of modern transportation.

Table 5. Number of fishes caught (in tons) by the Omani fishermen using traditional and/or modern transportation

\begin{tabular}{|l|c|c|c|c|c|c|}
\hline \multirow{2}{*}{\begin{tabular}{c} 
Number of fishes caught $\begin{array}{c}\text { Sin } \\
\text { tons) }\end{array}$ \\
\cline { 2 - 7 }
\end{tabular}} & \multicolumn{2}{|c|}{ Sohar } & \multicolumn{2}{c|}{ Muscat } & \multicolumn{2}{c|}{ Salalah } \\
\hline $0-100$ tons & 45 & 0 & 22 & 0 & 15 & 0 \\
\hline $101-200$ tons & 38 & 0 & 15 & 0 & 25 & 3 \\
\hline $201-300$ tons & 10 & 7 & 48 & 3 & 55 & 2 \\
\hline $301-400$ tons & 0 & 0 & 0 & 2 & 0 & 0 \\
\hline $401-500$ tons & 0 & 0 & 0 & 10 & 0 & 0 \\
\hline $501-$ and above tons & 0 & 0 & 0 & 0 & 0 & 0 \\
\hline Total & $\mathbf{9 3}$ & $\mathbf{7}$ & $\mathbf{8 5}$ & $\mathbf{1 5}$ & $\mathbf{9 5}$ & $\mathbf{5}$ \\
\hline
\end{tabular}

\section{Conclusion}

As evident on the data gathered form the 300 fishermen respondents of the study, Arab waters have immense potential when it comes to different types of fishes which surely make a way for future economic growth, exports and development of Oman. Thus, Sohar, Muscat and Shalalah are best examples for this study. The fish species that are "Most abundant" and "Abundant" in the area show high potential in the economic development of Oman. Moreover, the "Somewhat Abundant" types of fishes as mentioned in the results and discussions, are of great help to the country which attract more foreigners. It can therefore, contribute much on the economic development of Oman and its constituents. It implies further that as the area gets more modern in their way of living, better and greater technologies surface just like in Muscat.

The use of traditional and modern fishing method has an influence in the volume of fish being caught in a day. There is a significant relationship between the type of fishing transportation the respondents use in fishing and the implications it contributes to Oman's exports and economic development knowing the immense potential of the fisheries industry. Therefore, the null hypothesis is rejected.

Consequently, it is therefore recommended to give more symposiums or training on the modern fishing method as this will contribute in the development of fishing industry that will ultimately boost Oman's economy. The use of modern fishing method will also support the country's partnership with other foreign countries and private fishing industries that are well-versed with fishing technologies, without changing anything in their governmental laws.

\section{Acknowledgement}

The authors would like to thank International Maritime College Oman for providing the research facility as well as those who provide the possibility to complete this manuscript.

\section{References}

Al-Belushi, Kawther, Stead, Selina \& Burgess, James. (2015), The Development of Marine Biotechnology in 
Oman: Potential for Capacity Building Through Open Innovation". Marine Policy, 57, 147-157.

Al-Habsi, Manaa Saif \& Nik Mustapha, N.H. (2011), "Fisheries Sustainability in Oman". Journal of Economics and Sustainable Development, 2(7), 35-47.

Al-Habsi, Manaa Saif (2012), "The fisheries community of Albatinah Region in Oman: A Socio-Economic Review", Journal of Fisheries Science.com, 6(3), 215-223.

Al-Oufi, H., McLean, E. \& Palfreman, A. (2000), "Observation upon the Al-Batinah Artisanal Fishery, the Sultanate of Oman", Marine Policy, 24, 423-429.

Belwal, R., Belwal, S. \& Al Jabri, O. (2015), “The Fisheries of Oman: A Situation Analysis”, Marine Policy, 61, 237-248.

Bose, Shekar, Al-Masroori, Hussein \& Al-Habsi, Al Mutasam (2017), "Traditional Fisheries Enforcement Program: A Case of Three Coastal Villages in The Eastern Part of Oman”, Marine Policy, 78, 61-67.

Khan, Gulam Ali (2017), “Oman's Fisheries Sector Has Huge Potential for Growth: World Bank”, February 15, Retrieved from: https://m.muscatdaily.com

Al Abri, Mai. (2019), "Omani Fish Exports Soar to Record 245,000 Tonnes", Retrieved from: https://www.omanobserver.om/omani-fish-exports-soar-to-record-245000-tonnes/

MoAF. Muscat Daily (2018), "Fisheries Sector's Contribution to GDP to Increase Fivefold By 2023”, September 19, Retrieved from: http://omanwires.com/2018/fisheries-sectors-contribution-to-gdp-to-increase-five-foldby-2023-moaf/

Moustafa M. Fouda, Gregorio V. Hermosa Jr., \& Said M. Al-Harthi (1998), "Status of Fish biodiversity in the Sultanate of Oman”, Italian Journal of Zoology, 65(1), 521-525.

Setlur, Banu \& Arbuckle, M. W. (2015), "Sustainable Management of the Fisheries Sector in Oman: A Vision for Shared Prosperity”. Washington, D.C, World Bank Group Report.

Mubeen, S. A., Kumar, A. R. \& Nazneen, Q. (2017), "Economic Diversification in Sultanate of Oman Amidst Oil Crises", IOSR Journal of Business and Management, 19(6), 9-12.

Times of Oman (2017), "Fish Production in Oman Grows by 5.4\%", July 11, Retrieved from: https://timesofoman.com/article/112688/business/fish-production-in-oman-grows-by-54 